\title{
The Significance of Christian Love in Building a Stable Marriage
}

\begin{abstract}
"Anthropological and cultural changes in our times influence all aspects of life and call for an analytic and diversified approach"... families have come to enjoy greater freedom 'through an equitable distribution of duties, responsibilities and tasks'; indeed, 'a greater emphasis on personal communication between the spouses helps to make family life more humane', while 'neither today's society nor that to which we are progressing allow an uncritical survival of older forms and models'. It is also evident that 'the principal tendencies in anthropological-cultural changes' are leading 'individuals, in personal and family life, to receive less and less support from social structures than in the past'. On the other hand, 'equal consideration needs to be given to the growing danger represented by an extreme individualism which weakens family bonds and ends up considering each member of the family as an isolated unit, leading in some cases to the idea that one's personality is shaped by his or her desires, which are considered absolute.' 'The tensions created by an overly individualistic culture, caught up with possessions and pleasures, leads to intolerance and hostility in families'...today's fast pace of life, stress and the organization of society and labour, since all these are cultural factors which militate against permanent
\end{abstract}


decisions. We also encounter widespread uncertainty and ambiguity. For example, we rightly value a personalism that opts for authenticity as opposed to mere conformity. While this can favour spontaneity and a better use of people's talents, if misdirected it can foster attitudes of constant suspicion, fear of commitment, self-centredness and arrogance. Freedom of choice makes it possible to plan our lives and to make the most of ourselves. Yet if this freedom lacks noble goals or personal discipline, it degenerates into an inability to give oneself generously to others. Indeed, in many countries where the number of marriages is decreasing, more and more people are choosing to live alone or simply to spend time together without cohabiting."1 According to Pope Francis the marital and family life in postmodern society poses new challenges for spouses, parents and affianced couples.

In the current cultural, political, economic, social, educational and religious context numerous factors emerge which adversely affect the understanding, state and situation of marriage and the family. ${ }^{2}$ Postmodern society seems to be very hostile towards marriage and the family. At the root of present problems and challenges there is an attempt to promote a vision of the human being apart from God, and apart from Jesus Christ, a vision that is also leading to place the human in the centre of the world. ${ }^{3}$ Modern people seem to experience "a widespread existential fragmentation. A feeling of loneliness is prevalent; divisions and conflicts are on the rise." ${ }^{4}$ In connection with the growth of individualism in Europe, it is possible to observe many antifamily initiatives that weaken marital and family bonds, and consequently leave people feeling alone.

Amoris Laetitia 32-33.

2 Cf. E. Osewska, J. Stala, W kierunku katechezy rodzinnej, Kielce 2003; J. Stala, E. Osewska, Anders erziehen in Polen. Der Erziehungs- und Bildungsbegriff im Kontext eines sich ständig verändernden Europas des XXI. Jahrhunderts, Tarnów 2009; Religious Education / Catechesis in the Family. A European Perspective, eds. E. Osewska, J. Stala, Warszawa 2010; Education and Creativity, ed. E. Osewska, Warszawa 2014; The Contemporary Family: Local and European Perspectives, eds. E. Osewska, J. Stala, Kraków 2015; Focus on Family and Education, ed. E. Osewska, Split 2016; Rodzina bezcenny dar i zadanie, eds. J. Stala, E. Osewska, Radom 2006; Wychowanie a wyzwania ponowoczesności, ed. E. Osewska, Warszawa 2011; Rodzina i edukacja w zmaganiu o przyszłość Europy, ed. E. Osewska, Tarnów 2016; J. Stala, Familienkatechese in Polen um die Jahrhundertwende. Probleme und Herausforderungen, Tarnów 2008; Strengthening Families, eds. J. Stala, J. Garmaz, Kraków 2016.

3 Cf. Ecclesia in Europa 9.

$4 \quad$ Ecclesia in Europa 8. 
The lack of good models of marriage hinders the necessary preparation for taking up the role of a husband, father, wife or mother in a prudent and responsible manner. In this socio-cultural context, the reasonable, diligent and long-term preparation for bonding in a sacramental matrimony and establishing a family with a particular focus on understanding love is becoming indispensable. Pope Francis reminds us that "a love that is weak or infirm, incapable of accepting marriage as a challenge to be taken up and fought for, reborn, renewed and reinvented until death, cannot sustain a great commitment. It will succumb to the culture of the ephemeral that prevents a constant process of growth." ${ }^{5}$ Thus, in order for the Christian marriage to be built on the foundation of love it is essential to discover, recognize and accept its nature, to rise to the challenges it presents as well as to undertake consistent work on its growth. Even though love is a reality that man encounters every day, he or she sometimes attributes other meanings to it, reducing love to emotions, infatuation or desire. The present article will present the value of love and the importance of understanding its nature in building Christian marriage.

\section{God as the beginning and source of love}

Christianity accentuates that God, from the beginning, created man as a subject called to love, which is in Him and which is God Himself. "God created man in His own image and likeness: calling him to existence through love, He called him at the same time for love. God is love and in Himself He lives a mystery of personal loving communion. Creating the human race in His own image and continually keeping it in being, God inscribed in the humanity of man and woman the vocation, and thus the capacity and responsibility, of love and communion. Love is therefore the fundamental and innate vocation of every human being. As an incarnate spirit, that is a soul which expresses itself in a body and a body informed by an immortal spirit, man is called to love in his unified totality. Love includes the human body, and the body is made a sharer in spiritual love." God bonded human hearts with such a covenant that makes Him the love

5 Amoris Laetitia 124.

6 Cf. Familiaris consortio 11. 
which unites human hearts. Therefore, by participating in the love of Jesus Christ, Christian spouses are called to bear witness, with their life, to the love which the Lord revealed to humans in the Incarnation of His Son. The inner logic and dynamics of love turn man and woman towards God, who is love, the source and purpose of love. Human love, also the conjugal love, is an extension of Divine love. This is the fundamental feature of Christian love. ${ }^{7}$ The human love that is bereft of God's support is very brittle, volatile and fallible. Only when the human love is combined with God's love can it become strong, endure everything and persist against all odds. It is why the greatest commandment professed by Christianity is love. It also includes the dimension of love of man to woman, the sexual love, which, by nature, is to lead to the conjugal and family life.

Marital love fully reveals its true nature and nobility only when it stems from its original source, God, who is love and from whom every family in heaven and on earth is named. ${ }^{8}$ God created the human being, calling him/ her to existence in love and through love, He called him, at the same time, to love. Love is, therefore, the fundamental and innate calling of every human being. ${ }^{9}$ Love, while being the foundation of marriage, is also included in the love of God and stems from it. Thus, the preparation of young people for uniting in the holy matrimony cannot be devoid of presenting God as love. It must be borne in mind that God-Love is the ultimate purpose of all the creation and that love, understood in this way, emerges as the most important value which the contemporary man needs. The bond of love of

7 Cf. M. Czachorowski, Ku epoce rodziny, Łomianki 2000, pp. 62-63; H. Lombaerts, E. Osewska, The Modern Christian Family as a First Setting for Religious and Moral Education?, in: Religious Education/Catechesis in the Family: A European Perspective, eds. E. Osewska, J. Stala, Warszawa 2010, pp. 11-25; J. Stala, E. Osewska, Sociological Aspects of Family Religious Education in Poland, in: Religious Education / Catechesis in the Family. A European Perspective, eds. E. Osewska, J. Stala, Warszawa 2010, pp. 167-177; J. Stala, Der Mensch als Person: Die bestimmende Grundlage für Johannes Paul II. in seinem Bild von der Familie, „The Person and the Challenges" 2 (2012) nr 2, pp. 41-59; J. Stala, Die Transzendenz als bestimmendes Merkmal der Person in der Anthropologie und der Pädagogik Johannes Pauls II., „The Person and the Challenges" 2 (2012) nr 1, pp. 61-75.

8 Cf. Humane vitae 8.

9 Cf. Humane vitae 9; Redemptor Hominis 10; Familiaris consortio 11.13; Catechism of the Catholic Church 372-373; K. Wojtyła, Miłość i odpowiedzialność, Lublin 1982, p. 70; J. Laskowski, Małżeństwo wspólnota miłości, Warszawa 1993; W. Bołoz, Promocja osoby w rodzinie, Warszawa 1998, pp. 50-55; H. Krzysteczko, Pomoc w dojrzewaniu do miłości, matżeństwa i rodziny. Studium teologiczno-pastoralne, Katowice 2000, p. 49; F. Adamski, Rodzina. Wymiar społeczno-kulturowy, Kraków 2002, p. 201. 
spouses becomes the image and the symbol of the Covenant which unites God and His people. ${ }^{10}$

Thus, the Catholic Church reminds us that God Himself is the creator of marriage and conjugal love is part of the creative love of God and its reflection. ${ }^{11}$ Therefore, this love is, on the one hand, a gift and, on the other hand, a task given by God; it is the most imperative life vocation of man. ${ }^{12}$ In order to follow this vocation a man and a woman need proper preparation for marital life. A very important task lies before every man to distinguish between the true love and the so-called delusive love. According to the Church, one of the most significant causes of crises that the marriage faces presently is the incorrect understanding of the true sources of human and marital love.

\section{The Christological and ecclesial source of conjugal and family love}

Love comes from God, who revealed through so many signs His loving relationship towards people. "The communion of love between God and people, a fundamental part of the Revelation and faith experience of Israel, finds a meaningful expression in the marriage covenant which is established between a man and a woman. For this reason the central word of Revelation, 'God loves His people', is likewise proclaimed through the living and concrete word whereby a man and a woman express their conjugal love. Their bond of love becomes the image and the symbol of the covenant which unites God and His people."13 Indeed, once God came forth to His people with the offering of the covenant of love and fidelity, in the New Covenant the Saviour of people comes forth to Christian spouses through the sacramental marriage. ${ }^{14}$

The communion between God and people finds its ultimate fulfilment in Jesus Christ, the Bridegroom who loves and gives himself as the Saviour of humanity, uniting it to himself as his Body. He reveals the original truth

\footnotetext{
10 Cf. Familiaris consortio 12.

Cf. Genesis 1,28.

Cf. K. Wolski, Nazaret - źródło świętości, Łomianki 2001, p. 69.

Familiaris consortio 12.

14 Cf. Familiaris consortio 49; Gravissimum Educationis 3; Apostolicam actuositatem 11.30 .
} 
of marriage, the truth of the beginning, making man capable of realizing this truth. This revelation reaches its ultimate fullness in the gift of love which the Word of God makes to humanity in assuming human nature, and in the sacrifice which Jesus Christ makes of Himself on the Cross for His bride, the Church. In this sacrifice, that plan which God has imprinted on the humanity of man and woman since the moment of their creation is completely revealed. Therefore, conjugal love reaches its fullness when spouses, through their 'caritas', fulfil their participation and calling to experience the love of Christ, who offered Himself on the Cross. ${ }^{15}$

Jesus Christ teaches devoted, patient, self-sacrificing love to every Christian. Therefore, Christianity lays down stringent requirements to the married couple by calling them to fulfil a love that is patient, merciful and forgiving. In order to assist the husband and wife to rise to this challenge, the Church cares needs to prepare the young to realize this love in their everyday life. The ideal of conjugal love for Christians is the love of Jesus Christ to the Church. ${ }^{16}$ The love between Christian spouses is closely related to the love existing between Christ and the Church, i.e. a sacramental relation. Hence, only the sacrament of matrimony is the true calling and commandment for Christians called to marriage, which proclaims the requirement of remaining faithful to each other forever, beyond all trials and difficulties in generous obedience to the holy will of the Lord. ${ }^{17}$ The paradigm of the mystical espousal of Christ with the Church constitutes the best norm for relations between spouses "The spousal covenant, originating in creation and revealed in the history of salvation, takes on its full meaning in Christ and his Church. Through his Church, Christ bestows on marriage and the family the grace necessary to bear witness to the love of God and to live the life of communion." 18

15 Cf. Humane vitae 8.25.28; Familiaris consortio 13.15-17; F. Adamski, Rodzina. Wymiar społeczno-kulturowy, Kraków 2002, pp. 105-108; W. Bołoz, Promocja osoby w rodzinie, Warszawa 1998, pp. 243-244; H. Krzysteczko, Pomoc w dojrzewaniu do miłości, małżeństwa i rodziny. Studium teologiczno-pastoralne, Katowice 2000, pp. 50-53; E. Osewska, Jakość życia wspólnotowego rodziny jako podstawa skuteczności wychowania, „Roczniki Nauk o Rodzinie” (2013), t. 5, pp. 5-22; J. Stala, W kierunku integralnej edukacji religijnej w rodzinie. Próba refleksji nad nauczaniem Jana Pawła II w kontekście polskich uwarunkowań, Tarnów 2010.

16 Cf. Familiaris consortio 48.

17 Cf. Familiaris consortio 20.

18 Amoris Laetitia 63. 
The communal unity between husband and wife consists in the mutual self-giving. In the same way as Jesus Christ gave Himself for the Church, so too, believing spouses - baptised and living in the sacramental marriage, give themselves to each other. Similarly, just as Jesus Christ never abandoned His bride - the Church, so too, spouses are to remain faithful to each other until death. The sacrament of matrimony allows man and woman, united by love, to truly participate also in the love of Jesus Christ to the Church, and, at the same time, His work of salvation. All Christians are responsible for the gift of evangelical love and its fulfilment. Jesus Christ comes with requirements and sets Himself as a norm, a criterion and purpose of all the human activity. The principal tenets of His teaching, and, at the same time, the programme of human life, were summarized by Jesus in the "Sermon on the Mount". The ideal of human life presented in it is not meant as something that can be simply maintained but rather as a goal which needs to be sought slowly, consistently and patiently. Thus, not only does Jesus make a correction of the obligations and prohibitions but also presents the positive programme of Christian life in blessings. The blessings, together with the new commandment of love, make up the constitution of Christianity. ${ }^{19}$ Only by taking steps on the path of evangelical love, following Jesus Christ as an ideal model for life, can the human being draw near to God and achieve true excellence.

\section{Conjugal love as a gift of oneself ennobled by the sacrament}

In postmodern society, a society that induces man to care obsessively for oneself, the Catholic Church reminds us the truth behind marriage and the family as a community of persons endowing each other with a gift of love. This gift of oneself which is meant to enliven the mutual love of spouses can still be the model and principle of functioning in marriage. ${ }^{20}$ This mutual personal gift in marriage opens up, at the same time, to the gift of a new life, the gift of a new human. The gift of inner readiness to bring a child into this world is related to the marital union, which ought to constitute an extraordinary moment of a mutual exchange of the gift of oneself between

19 Cf. J. Zabielski, Biblijna aksjologia życia społecznego chrześcijan, „Rocznik Teologii Katolickiej” 10 (2011) pp. 88-102.

20 Cf. Familiaris consortio 37. 
a woman and man. The entire human being takes part in this act of giving, thus, also his body, which, owing to its sexuality, also expresses man's calling for reciprocity, i.e. for love and the mutual gift of oneself. ${ }^{21}$

A fully human love should always be a love of persons. The human being, as a person, is capable of friendship and devotion to the extent that we may acknowledge and love a person for who they are. A human person wishes and wants the good of another person because he sees him as worthy of being loved. It is a gift of oneself offered to the one who is loved, and in whom we may discover and fulfil our own good, the good of the communion of persons as well as learn the value of loving and being loved. ${ }^{22}$

When a human loves someone, he wishes to live with and spend time together with that person, jointly take on day-to-day challenges, but, from the Christian perspective, it is not sufficient. A human person who loves needs to get to know, understand and to empathize with the needs of the other person as well as to make decisions together. ${ }^{23}$

A distinguishing feature of a mature love is forsaking one's own egoism for the sake of the community of two persons in which each person cares for the good of the other. Mature love is characterized by the joint responsibility. Both spouses bear the responsibility for setbacks, similarly, they are both makers of their own satisfaction and happiness. ${ }^{24}$ According to John Paul $\mathrm{II}^{25}$, this reveals the truth and power of love, which is capable of standing in between the forces of good and evil, which battle within each man, and will do anything in its power to aid the good in winning since it believes in its victory. To quote St. Paul, it may be added that "love is patient and kind; love does not envy or boast; it is not arrogant or rude. It does not insist on its own way; it is not irritable or resentful; it does not rejoice at

21 Cf. Amoris Laetitia 163-167.

22 Cf. Gratissimam Sane 9.

23 Cf. M. Braun - Gałkowska, Psychologia domowa, Olsztyn 1985, p. 31; E. Osewska, The Basic Assumptions of Child Upbringing in the Family. Modern Implications, in: The Contemporary Family: Local and European Perspectives, eds. E. Osewska, J. Stala, Kraków 2015, pp. 249-261; E. Osewska, Value education in the Polish family, in: Strengthening Families, eds. J. Stala, J. Garmaz, Kraków 2016, pp. 303-316; J. Stala, Punina postojanja osobe - civilizacija ljubavi u kontekstu postmoderne, „Crkva u svijetu” (2015) nr 3, pp. 469-477; J. Stala, Christliche Wahrheiten als Fundament einer inhaltsreichen Religionserziehung in der Familie, "The Person and the Challenges" 5 (2015) nr 2, pp. 137-148.

24 Cf. M. Ryś, Psychologia małżeństwa, Otwock 1997, pp. 25-26.

25 Cf. Jan Pawel II, Mężczyzna i niewiasta stworzył ich. Odkupienie ciała a sakramentalność małżeństwa, Vatican 1986, pp. 447-448. 
wrongdoing, but rejoices with the truth. Love bears all things, believes all things, hopes all things, endures all things. Love never ends" (1 Corinthians 13:4-8). All activities directed at a spouse ought to be grounded on the conviction that one is obliged to assist their fiancé/fiancée or spouse in fulfilling their humanity in order for them to become a more mature human being. ${ }^{26}$ Realizing love and adopting the stance of devotion constitute the sine qua non condition for the fulfilment of a human as man. Therefore, if one affirms the other person only for one's own self-actualisation, this is an act against love. ${ }^{27}$ The category of one's selfless gift of oneself takes on particular importance in holy matrimony, where man and woman have been created in such a way as to reciprocally endow each other with the wealth of their humanity through their distinctness. The fact that spouses, who simultaneously give of themselves to each other, are persons, means that their conjugal coexistence attains the status of a reciprocal gift of one person to the other. This gift means that spouses give not only what they possess, but rather who they are. ${ }^{28}$

Furthermore, ideas stating that marriage serves the purpose of expressing, developing and maturing the mutual love seem to define conjugal love along the lines of the reciprocal gift of man and woman. Being a gift for another person is the fullest interpretation of the Christian calling of each human being. ${ }^{29}$ The sincere gift that a human may bestow on another human is an essential element of a lasting and irrevocable marital and family love. Man and woman are a 'gift' to each other, one that the Creator bestows upon another man, therefore, they become self-actualising subjects only when each of them exist with someone, and, even more deeply and completely, if they exist for someone. Hence, being a person in the image and likeness of God means living in a relation, being in relation to another 'I'. Thus, the communion of persons always entails the existence of a relation of a reciprocal gift. For this reason a person is called to live in the interpersonal relation of love and unmitigated self-giving. ${ }^{30}$ In accordance with the plan of the Maker, man

\footnotetext{
26 Cf. A. d’ Heilly, Miłość i sakrament, Warszawa 1983, p. 16.

27 Cf. Jan Paweł II, Mężczyzna i niewiasta stworzył ich, p. 58.

28 Cf. T. Styczeń, Ciało jako znak obrazu Stwórcy, in: Jan Paweł II. Mężczyzna i niewiastą stworzyt. Chrystus odwołuje się do początku, Lublin 1981, p. 110.

29 Cf. J. Homplewicz, Pedagogika rodziny. Zarys wykładów na podyplomowym studium prorodzinnym, Rzeszów 2000, p. 146.

30 Cf. K. Wolski, Nazaret - źródło świętości, Łomianki 2001, pp. 71-72; Jan Paweł II, Mężczyzna i niewiasta stworzył ich, Watykan 1986, pp. 285-333.
} 
and woman are complementary, which enables them to complete each other on the physical, psychological and spiritual plane: manhood reaffirms itself through womanhood and womanhood emerges only via manhood. Both are mutually channelled towards each other, not only in terms of their bodily structure but, above all, in relation to the dialogical character of the other person: "I" may fully fulfil itself only in "you".

The grace of the sacrament of holy matrimony is the reason why a man is guided towards a woman and a woman towards a man. ${ }^{31}$ The woman-wife, through her inner and, as it were, innate propensity to love and be loved, makes herself a spousal gift for a man and, at the same time, she evokes in him the stance of being a gift, which itself actualizes being a person. ${ }^{32}$ Man and woman are a gift to each other when each of them exists together with the other and, more deeply and completely, if he or she exists "for someone."33

But it is worth remembering that in the sacramental marital love, not only the spirit, but also the human body is an expression of this personal gift. That is precisely why, every loving gesture, all non-verbal communication expressed through human body supports the growth of marital love. In building a personal marital love between man and woman sexual intercourse is an integral element that even determines the validity of a contracted sacramental marriage. ${ }^{34}$ In terms of the uniqueness of marital love a call to spouses to shape the marital community on the foundation of pure love does not mean depreciation of sexuality, but a defence against its deformation. "Sexuality is respected and promoted in its truly and fully human dimension, and is never "used" as an "object" that, by breaking the personal unity of soul and body, strikes at God's creation itself at the level of the deepest interaction of nature and person." ${ }^{35}$ But the gift of sexuality is

31 Cf. J. Stala, $W$ kierunku integralnej edukacji religijnej $w$ rodzinie. Próba refleksji nad nauczaniem Jana Pawła II w kontekście polskich uwarunkowań, Tarnów 2010; J. Stala, Katecheza rodzinna w nauczaniu Kościoła od Soboru Watykańskiego II, Tarnów 2009; J. Stala, Katecheza o małżeństwie i rodzinie w Polsce po Soborze Watykańskim II. Próba oceny, Tarnów 2004.

32 Cf. S. Stefanek, Pedagogia serca i ciała - duchowość małżeńska i rodzicielska, Communio 6 (1986) no. 6, p. 48.

33 Cf. K. Wolski, Nazaret - źródło świętości, Łomianki 2001, pp. 71-72.

34 Cf. M. Komorowska-Pudło, Seksualność młodzieży przełomu XX i XXI wieku, Kraków 2013, pp. 25-26.

$35 \quad$ Familiaris consortio 32. 
not given in a mature form, so it is Christian's obligation to develop this gift in connection with the emotional and spiritual spheres.

Through this gift, marital love is a reflection of Divine love and is, in fact, inseparable from parenthood. Against the background of this ultimate spousal grace, it is easy to see that all activities aimed against parenthood distort the inner truth of conjugal love, which is devoted to the complete personal gift. ${ }^{36}$ The unique character of the bond between a husband and his wife makes them, first and foremost, a community of love, open to a new life. ${ }^{37}$ This love, however, is not something that is attained once and for all. It must not be forgotten that the condition for the true marital love is always the acceptance of the other person, manifested in giving oneself to someone. Only love understood and fulfilled in this way may provide the feeling of happiness in the marital and family life.

The present sociocultural perception of marriage is the result of a complex process and many factors. $21^{\text {st }}$ century society is to be associated with a major shift in life conditions that often force people to make up their mind and take decisions in response to completely unknown and unpredictable challenges. In that sense, changes in the development of the social, cultural, moral, religious, contextual responses to new challenges affect the perception of interpersonal relationships, of sacraments and the sense of belonging to the Church. The Church is becoming increasingly aware that the pastoral care of marriage and people preparing for marriage encompasses also various groups of people in special circumstances: couples expecting children, couples cohabiting for long time, pairs separated by migrations, widows and widowers, divorced etc., so it is important not to overlook the spouses in difficult and unsettled circumstances, but to support conjugal love as a dynamic and multi-faceted reality since it is, at the same time, physical and spiritual, open to God and to the other person. It also requires giving up oneself for the sake of the new "we". For this reason, spouses need to learn the true nature and dignity of love from the perspective of theology, philosophy, psychology, in order to better comprehend it, and, in turn, embrace it, undertake it and fulfil its demands in the daily life.

\footnotetext{
36 Cf. Familiaris consortio 32.

37 Cf. Familiaris consortio 28.
} 


\section{Bibliography}

Adamski F., Rodzina. Wymiar społeczno-kulturowy, Kraków 2002.

Braun-Gałkowska M., Psychologia domowa, Olsztyn 1985.

Czachorowski M., Ku epoce rodziny, Łomianki 2000.

d’ Heilly A., Miłość i sakrament, Warszawa 1983.

Education and Creativity, ed. E. Osewska, Warszawa 2014.

Focus on Family and Education, ed. E. Osewska, Split 2016.

Homplewicz J., Pedagogika rodziny. Zarys wykładów na podyplomowym studium prorodzinnym, Rzeszów 2000.

Komorowska-Pudło M., Seksualność młodzieży przełomu XX i XXI wieku, Kraków 2013.

Krzysteczko H., Pomoc $w$ dojrzewaniu do miłości, małżeństwa $i$ rodziny. Studium teologiczno-pastoralne, Katowice 2000.

Laskowski J., Małżeństwo wspólnota miłości, Warszawa 1993.

Lombaerts H., Osewska E., The Modern Christian Family as a First Setting for Religious and Moral Education?, in: Religious Education/Catechesis in the Family: A European Perspective, eds. E. Osewska, J. Stala, Warszawa 2010, pp. 11-25.

Osewska E., Jakość życia wspólnotowego rodziny jako podstawa skuteczności wychowania, „Roczniki Nauk o Rodzinie” (2013), t. 5, pp. 5-22.

Osewska E., Stala J., W kierunku katechezy rodzinnej, Kielce 2003.

Osewska E., The Basic Assumptions of Child Upbringing in the Family. Modern Implications, in: The Contemporary Family: Local and European Perspectives, eds. E. Osewska, J. Stala, Kraków 2015, pp. 249-261.

Osewska E., Value education in the Polish family, in: Strengthening Families, eds. J. Stala, J. Garmaz, Kraków 2016.

Bołoz W., Promocja osoby w rodzinie, Warszawa 1998.

Religious Education / Catechesis in the Family. A European Perspective, eds. E. Osewska, J. Stala, Warszawa 2010.

Rodzina bezcenny dar i zadanie, eds. J. Stala, E. Osewska, Radom 2006.

Rodzina i edukacja w zmaganiu o przyszłość Europy, ed. E. Osewska, Tarnów 2016.

Ryś M., Psychologia matżeństwa, Otwock 1997. 
Stala J., Christliche Wahrheiten als Fundament einer inhaltsreichen Religionserziehung in der Familie, "The Person and the Challenges” 5 (2015) nr 2, pp. 137-148.

Stala J., Der Mensch als Person: Die bestimmende Grundlage für Johannes Paul II. in seinem Bild von der Familie, "The Person and the Challenges” 2 (2012) nr 2, pp. 41-59.

Stala J., Die Transzendenz als bestimmendes Merkmal der Person in der Anthropologie und der Pädagogik Johannes Pauls II., „The Person and the Challenges" 2 (2012) nr 1, pp. 61-75.

Stala J., Familienkatechese in Polen um die Jahrhundertwende. Probleme und Herausforderungen, Tarnów 2008.

Stala J., Katecheza o małżeństwie i rodzinie w Polsce po Soborze Watykańskim II. Próba oceny, Tarnów 2004.

Stala J., Katecheza rodzinna w nauczaniu Kościoła od Soboru Watykańskiego II, Tarnów 2009.

Stala J., Osewska E., Anders erziehen in Polen. Der Erziehungs- und Bildungsbegriff im Kontext eines sich ständig verändernden Europas des XXI. Jahrhunderts, Tarnów 2009.

Stala J., Osewska E., Sociological Aspects of Family Religious Education in Poland, in: Religious Education / Catechesis in the Family. A European Perspective, eds. E. Osewska, J. Stala, Warszawa 2010, pp. 167-177.

Stala J., Punina postojanja osobe - civilizacija ljubavi u kontekstu postmoderne, „Crkva u svijetu” (2015) nr 3, pp. 469-477.

Stala J., $W$ kierunku integralnej edukacji religijnej w rodzinie. Próba refleksji nad nauczaniem Jana Pawła II w kontekśsie polskich uwarunkowań, Tarnów 2010.

Stefanek S., Pedagogia serca i ciała - duchowość małżeńska i rodzicielska, Communio 6 (1986) no. 6.

Strengthening Families, eds. J. Stala, J. Garmaz, Kraków 2016.

The Contemporary Family: Local and European Perspectives, eds. E. Osewska, J. Stala, Kraków 2015.

Wojtyła K., Miłość i odpowiedzialność, Lublin 1982.

Wolski K., Nazaret - źródło świętości, Łomianki 2001.

Wychowanie a wyzwania ponowoczesności, ed. E. Osewska, Warszawa 2011.

Zabielski J., Biblijna aksjologia życia społecznego chrześcijan, „Rocznik Teologii Katolickiej” 10 (2011) pp. 88-102. 
